\title{
Liberating language and concepts of the divine in contemporary hymnody
}

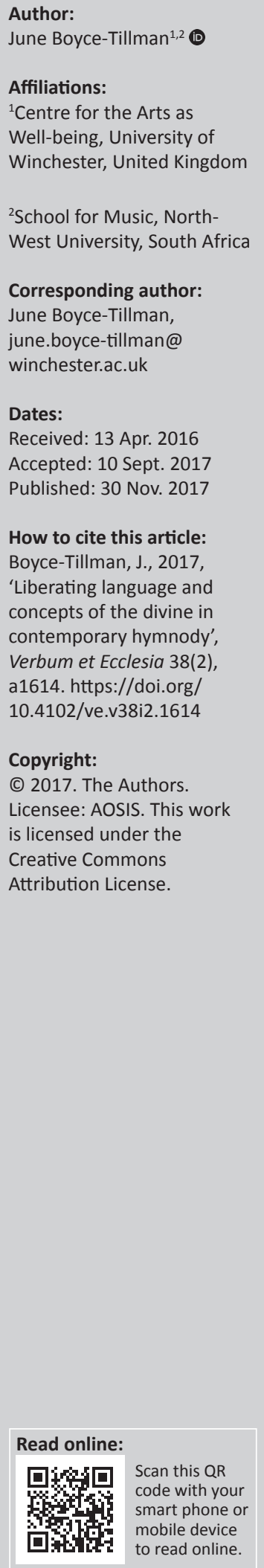

This article will examine from an auto-ethnographic perspective the language of hymnody and how it has developed over the last 25 years through the period of secularisation and postsecularisation. It will interrogate and analyse the words used for the Divine in a drive towards an inclusive language approach to God. It will look at the arguments of feminist theologians towards feminine images for the Divine and then how far these images will be acceptable in secular contexts, especially in secular rituals that include people from a variety of belief backgrounds in a post-secular world. It will use examples from woman writers and draw on the author's experience of revising her own hymns for a variety of contexts. These will be interrogated in the light of debates around spiritual but not religious, multifaith dialogue and post-secularisation. It will look at a variety of approaches to the Christian narrative in contemporary UK - devotional, cultural and story - examining the language appropriate for these various approaches and various contexts.

Intradisciplinary and/or interdisciplinary implications: Hymnology crosses the disciplines of music, theology, liturgy and ritual (sacred and secular) and has implications for all these areas, especially Church liturgy and sacred music in secular contexts. It is lyrical theology, which spans the arts and theology and expresses theological ideas in an artistic form.

\section{Introduction}

This article will examine from an auto-ethnographic perspective (Boyce-Tillman 2006) the language of hymnody (Wren 1989) and how it has developed over the last 25 years through the period of secularisation and post-secularisation (Carrette 2000). I will draw on a wide variety of disciplines from music, education, humanistic psychology (particularly Assagioli 1994; Myers 1993; Myers \& McCaulley 1985), sociology, gender studies and theology (particularly Grey 1993; Fiorenza 2000; Isherwood \& Stuart 1998; McEwan, Pinsent, Pratt \& Seddon 2001; Neu 2003; Stuart 1996; Wootton 2000). I have identified certain polarities, which are in dynamic relationship (Boyce-Tillman 2000). These are woven together in this article. It weaves many strands and traditions with their associated methodologies (Richardson 2000). I have gradually moved towards this way of working and presenting, which sees truth as a crystal with different facets revealing different aspects of truth.

Crystallisation combines multiple forms of analysis and multiple genres of representation into a coherent text or series of related texts, building a rich and openly partial account of a phenomenon that problematises its own construction, highlights researchers' vulnerabilities and positionality, makes claims about socially constructed meanings and reveals the indeterminacy of knowledge claims even as it makes them (Ellingson 2009:4).

In line with this crystallisation methodology (Richardson 2000) it sets out a complex landscape made up of pieces similar to those of a jigsaw without a completed image. It does not make claims to a definitive truth (Haraway 1988), but sets itself up as a survey of a landscape and the variety of methodologies that might be used to explore it. It will examine the competing truth claims of various traditions and individuals, power relations and where spirituality or spiritualities fit within these.

I propose that the central image for 'validity' for postmodern texts is not the triangle - a rigid, fixed, two-dimensional object. Rather, the central imagery is the crystal, which combines symmetry and substance with an infinite variety of shapes, substances, transmutations, multidimensionalities and angles of approach (Richardson 2000:934).

\section{Contemporary spirituality}

Elsewhere (Boyce-Tillman 2016:25-79) I have analysed the development of religionless spirituality and identified the following strands within it. Other people have found these 
possibilities as sources of spiritual experiences (James 1902/1997; Pratt 2012).

\section{Metaphysical}

Here people encounter mystery and are often helped by contemplative practices. This links with the experience of 'contemplative thinking' (Lancaster 2004). There is a sense of the beyond - the All shall be well of the mystic, Julian of Norwich - a releasing of control - a sense of connection to a life-force, God, higher power or purpose, often called by a variety of names.

\section{Intergaian}

For this strand people draw their experience of the spiritual from a sense of oneness and deep relationship with the otherthan-human world (Boyce-Tillman 2001; Boyce-Tillman 2016:139-158; Grey 2007; Primavesi 2008).

\section{Narrative}

A particular holy story or religion gives meaning to my life. This is often the beginning of an affiliation to a particular religion. In my case this has been the Christian narrative and the Jesus story still holds me sufficiently to keep that linkage with Christianity.

\section{Interpersonal}

Here the main emphasis is on the interrelationship with other people - a sense of belonging and being at ease in the world and replacing competition with caring and attempts to bless (Buber 1970; Laurence 2008).

\section{Intrapersonal}

This strand, which concentrates on relationships within the self - including mood and transformation (Boyce-Tillman 2009), has many varied emphases within it. Empowerment, bliss and realisation are found in many texts, which often results in an increase of energy and greater clarity. Sometimes this is linked with a sense of coming home to be at peace and at one with ourselves, '... the joy and reconciliation of better knowing ourselves ... and the unity of being at peace with ourselves' (Jorgensen 2008:280). This experience is often evanescent and fleeting and unable to be managed or controlled by the experiencer. This is often linked with a sense of coming from the beyond the self with a mixture of grace, insight and effort (Tisdell 2007:533). This is often linked with freedom - a feeling of an opening-up in the experiencer as boundaries start to dissolve. This sets a person free to experiment with new ways of being. This leads to an increase in open-mindedness and curiosity - a creativity born from unusual associations described by Koestler (1964) as bisociation. This seems to originate in the unconscious and may be manifested in image, symbol, music and other enculturated expressions. Here paradox co-exists easily (Clarke 2008:172).

\section{Extrapersonal - Ethical}

This is characterised by a feeling of unity with other beings, people and the cosmos (communitas) (Turner 1982:44). The peace building in the mind extends beyond this to the whole cosmos. There is a sense of cosmic leading often manifested in ethical behaviour to other cultures. This often gives people a sense of a greater purpose and meaning to their lives.

I am going to chart the strands as they have echoed through my thinking, concentrating on a hymn I wrote in 1993 and how it has been changed to reflect post-secularism. The hymn was written originally as a politically correct wedding hymn, but it has found its way into many contexts because of its opening line, especially with Lesbian, Gay, Bisexual, Transgender and Intersex communities. This is its original form (Boyce-Tillman 2006):

1 We sing a love that sets all people free, That blows like wind, that burns like scorching flame, Enfolds like earth, springs up like water clear. Come, living love, live in our hearts today.

2 We sing a love that seeks another's good, That longs to serve and not to count the cost, A love that, yielding, finds itself made new. Come, caring love, live in our hearts today.

3 We sing a love, unflinching, unafraid To be itself, despite another's wrath, A love that stands alone and undismayed. Come, strength'ning love, live in our hearts today.

4 We sing a love that, wand'ring, will not rest Until it finds its way, its home, its source, Through joy and sadness pressing on refreshed. Come, pilgrim love, live in our hearts today.

5 We sing a burning, fiery, Holy Ghost That seeks out shades of ancient bitterness, Transfig'ring these, as Christ in ev'ry heart. Come joyful love, live in our hearts today. (p. 83)

I am going to analyse the text using the strands in spirituality outlined above.

\section{Metaphysical - The struggle for inclusive language for the divine}

God remained male for me for 30 years until I found feminism and the possibility of Mother God, Sister God, midwife God and God the masseuse. A deeply religious child, I did not realise what the maleness of God had done to me - it had been so internalised that patriarchy did not seem to be imposed but a given - like God. It was a neat way to make women subject to men - to accept the status quo submissively and unquestioningly. I had to rename God to find my own power and realise what patriarchal theology had done.

In the 1990s the desire among woman for inclusive language in hymnody was growing. The issues are very complex.

1. ${ }^{\circ}$ Copyright 1993 Stainer \& Bell Ltd. In the final verse Holy Ghost is used deliberately to counteract the 'shades of ancient bitterness'. Though the use of this archaism has been questioned, sometimes an older word can be reclaimed now with a powe lacking in more familiar words. 
The least contentious aspect of it concerned inclusive language for human beings. The third person pronoun 'he' has traditionally been used as an inclusive pronoun, as has the generic term 'man'. Organisations like The Association for Inclusive Language have shown that the use of these terms was confused and that women were disadvantaged by the use of these terms which were sometimes used as inclusive and at other times as exclusive of women. I wrote this hymn for them:

\section{COUNT ME IN}

1. On a day when all were counted,

Mary found no place to rest,

Pressing forward with her burden,

Sharing in our homelessness.

2. Jesus, born of exiled mother,

Healer, friend of all the oppressed,

Be with all who feel excluded

From the circles of the blessed.

3. You were also once at variance

With the custom of your day,

Breaking bonds of race and gender

In your friends along the way.

4. Sister, brother, wife and mother

Could these all be names for you?

Counsellor of ancient Wisdom,

We would to ourselves be true. ${ }^{2}$ (June Boyce-Tillman 2006:57)

Feminist writers have therefore pushed hard for the use of inclusive descriptors of people. This involved finding nonmale descriptors for people - like human rather than man and avoiding the third person singular pronoun 'he' and using the third person plural 'they'. Feminist musicians' writing material for women's gatherings were producing material addressed only to women, such as Marsie Silvestro (1993):

Refrain: We are weaving a revolution, many women, many threads

And through our cultures and with our spirit

A healing power will rise from earth. (Sleeve notes:n.p.)

Feminine images for human-beings are not strictly speaking inclusive; they simply replaced male with female. Inclusive descriptors are gender-neutral. But we have had such a long period in which hymns like Rise up O men of God! have held their place, that maybe there is a case for a similar period when female descriptors are used to rebalance this.

There is a well-established theology of God as male reflected throughout the hymnody of the Church. Some contemporary women do not find it a problem and some men do. Contemporary writers in the evangelical tradition find the male images very acceptable; Graham Kendrick (2003) writes that the characteristics of true Christian worship fall under the headings:

Worship the Father

In Spirit

In truth (p. 92)

2. ${ }^{\circ}$ Copyright 1993 Stainer \& Bell Ltd.
Other writers who take a Trinitarian approach, like Carl Daw, manage to treat the area traditionally associated with God the Father in inclusive ways with hymns like:

God of wombing, God of Birth,

God who formed us from the earth ... (Daw 1996:42)

But new hymns in the 1990s needed to be inclusive and people set about it in various ways. People gave people a chance to change hymns as they chose. ${ }^{3}$ The Unitarian/ Universalist hymnbook (1993) contains many fine examples of how the past can be reworked. The fine prophetic hymn Turn back, O Man becomes Turn back, turn back. The final verse of Now Thank we all our God, which starts - 'All praise and thanks to God the Father now be given' - is simply omitted. In O Little town of Bethlehem, 'the blessings of his love' becomes 'the gift that is our own' (Unitarian/Universalist Hymnbook No 247). However, the changing of more familiar material can cause much more uproar in a traditional congregation than the writing of new material with inclusive language. Carl Daw (2003) makes the distinction:

And so, we always have to make a distinction between the hymn as we encounter it and the hymn as we have experienced it, because they may not be the same at all ... It's absolutely essential, first of all, that all language for people be inclusive ... [But] there are places where I would want to reserve historic texts because I wouldn't want to muck about with them. (Interview:n.p.)

Another possibility is to use non-gendered descriptors for God like friend, companion, et cetera, and healer is one solution - the truly inclusive one. We find this in material from that past such as Margaret Cropper's (1886-1980):

O Christ, whom we may know and love

And follow to the end,

We who are friends together come

To thee our heavenly friend. (Boyce-Tillman \& Wootton 1993:76)

Dorothy Gurney's (1858-1932) wedding hymn addresses God as:

O perfect love, all human thought transcending. (Boyce-Tillman \& Wootton 1993:75)

Sydney Carter frames a wonderful hymn about creativity around the image:

The bell of creation is swinging for ever

In all of the things that are coming to be ... (Boyce-Tillman \& Wootton 1993:65)

\section{I used the word energy:}

Deep in creation's heart an energy

Calls to us but leaves us free;

Dance with that universal energy,

Celebrate life's mystery ...

4. Boundless supplies there are of energy

Strengthening us in loving ways;

Changeless dynamic vital energy

Dance within us all our days. (Boyce-Tillman 2006:108)

3.'Service sheet of St James', Piccadilly, London, Jan 162005. 
In extending the notion of an inclusive community, there is clearly a need for a reconnection with the natural world, especially the image of the earth, which has been traditionally marginalised by the Church. This had led to the rediscovery of the Celtic traditions. Betty Wendelborn draws on a favourite image of the ancestry of the earth:

Grandmother earth,

Holy be your name. (Boyce-Tillman \& Wootton 1993:56)

In Doug Constable's hymn written for the 25th anniversary of the World Wildlife Fund, God is addressed as:

Warm God of seeds, all nature's source,

Womb of earth maker, and love's stirring pulse. (Boyce-Tillman \& Wootton 1993:66)

Shirley Erena Murray's (1996) hymn hears the earth crying out:

I am your mother: do not neglect me!

Children protect me - I need your trust:

My breath is your breath

My death is your death,

Ashes to ashes, dust into dust. (p. 16)

The use of feminine images for God is not, strictly speaking, inclusive and opinion is much divided here. Feminists see the use of the feminine images for God essential, while others see it as potentially as divisive as the older male language. For example, Janet Wootton's hymn Dear Mother God starts:

Dear Mother God, your wings are warm about us. (BoyceTillman \& Wootton 1993:1)

Janet says that it has raised a storm when it has been used in some circles, but it is completely scriptural, based on the Eagle image from Deuteronomy. She comments on people's response to feminine images:

There is something visceral in people's response, which even reference to Scripture and tradition will not allay. (Wootton 2003:134)

Mel Bringle also uses feminine images from Biblical sources like:

Held in the shelter of God's wing,

Terrors of the night we need not fear ...

Mother and midwife, cradling arms,

Comfort when strength dries up like dust ... (Bringle 2002:56)

There is also in Reflecting Praise, Judith Driver's fine hymn, My God is woman:

4. My God is woman:

She is around me and in me;

She is darkness and light;

She creates and heals ... (Boyce-Tillman \& Wootton 1993:4)

I tried to establish a charismatic female figure like Dylan's $\mathrm{Mr}$ Tambourine Man in The Tambourine Woman, with its dancing Irish style tune and the chorus:

We'll follow the tambourine woman

And join in her tambourine song.
We're riding a rainbow to heaven

And dancing our journey along. (Boyce-Tillman \& Wootton 1993:62-63)

Brian Wren's hymn moves to a genderless deity from a feminine pronoun:

Who is She,

Neither male or female,

Maker of all things,

Only glimpsed or hinted,

Source of life and gender? (Boyce-Tillman \& Wootton 1993:8)

Pat Michaels (2003) in Cambridge, Massachusetts, sees the transformative power of feminine images of God. To illustrate this, he describes the effect of female imagery on a heterosexual male worshipper, who then said how he had to review both his relationships with women and with his own mother:

I've got a couple of texts where I decided I was going to write a hymn with female imagery for God, and just figure out how to do that in a non-sexist kind of way - non-stereotypical way, which was hard ... I took each stanza and tried to focus on some woman in my life, and write something about who God is through that person, and my mother was one stanza: The Holy Spirit Came to Me ... She fed and clothed me, worked and played; she showed me how to look and see the world and not to be afraid. (Interview:n.p.)

What he was demonstrating very clearly is a truly incarnational Wisdom theology where we find Christ in the people we meet.

To summarise, we see a move towards a greater diversity of images for God as people examine female images and metaphors in this area. There are few hymns that represent the goddess thinking within the thealogy ${ }^{4}$ tradition and any female image needs introducing with caution to a mainstream congregation.

\section{Idolatry}

As part of the research project around my composition (2001/2012), The Healing of the Earth, I ran focus groups of children on their views of God. In one secular school, I had a group of bright 9 and 10 year olds. Three of them started on their atheism. God was an old man in the sky and they did not believe in him. They failed to see the illogicality of this position. When they had explored their position fully, the little Muslim girl who was sitting on my left came in with her contribution: 'We do not have any images of God in Islam'. This horrified the atheists who instantly knew that they desperately needed images of God in order to be atheists. Under pressure she thought quickly: 'I suppose if we have no images of God we could call God he, she or it'. It was the last place where I had expected to find the feminine in God, and I realised how much freer Judaism and Islam were with their patterns and their obedience to the second commandment. I had often wondered why it was so high up and suddenly

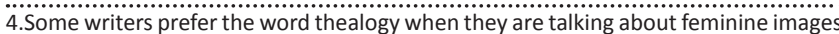
of God (Mantin 2002; Raphael 1999). 
I understood. It was from the Islamic and Jewish traditions that I could rethink idolatry. It is wrong because it excludes people and Christianity has done this very effectively over its history. Richard Dawkins (2007) alerted us to this in The God Delusion. This could not have been written but for the vast quantity of images of God as an old man such as the Sistine chapel ceiling. In the end I codified my thoughts in a hymn:

\section{FINDING GOD \\ A child once loved the story- \\ Which angel voices tell - \\ How once the King of Glory \\ Came down on earth to dwell.}

Now, Father God, I miss you -

Your beard, your robes, your crown -

But you have served us badly

And let us humans down.

So easy to disprove you

And doubt your truthfulness;

For you were just an idol

That kept Your power suppressed.

For You are deep within us -

Revealed within our deeds,

Incarnate in our living

And not within our creeds.

No image cannot hold you;

And, if to one we hold,

We keep some from your loving

And leave them in the cold.

Excluded groups are legion -

Disabled, female, gay -

Old Father of the heavens,

Your picture moves away.

Life's processes reveal You -

In prison, death and war,

In people who are different,

In gatherings of the poor.

For Godding means encounter,

Gives dignity to all,

Has every shape and no shape -

In temple, tree and wall.

So we will go a-godding

And birth You in our world;

In sacrificial loving

We find Your strength unfurled. (Boyce-Tillman 2014:180-181)

\section{Jesus and the goddess}

In the 1990s I was deep into the New Age (with one foot still in the Church). I had attended the solstice celebrations at Stonehenge along with 10000 other people including Buddhists chanting, a choir from New Zealand, a gong player seeking resonance from the heel stone and several groups of drummers. I had already been immersed in the pagan context with its ubiquitous incense sticks and candles, for it had healed me from long-term illness using indigenous traditions, herbal medicines and trance. It was a book entitled Embracing Jesus and the Goddess (McColman 2001) that influenced me to see that interfaith dialogue should include goddess traditions.
This coincided academically with the search for the historical Jesus and an understanding of the way in which the Jesus story had been transmitted. In The Christ Myth and the Christian Goddess Robert Price (2016) explores what he calls Jesus constructs:

Some paint him as a peasant revolutionist, violent or non-violent. Others make him a magician. Some an apocalyptic prophet, others a wandering sage. (n.p.)

But he concludes that the historical Jesus will remain mysterious. He cites the permeation of even early New Testament texts with Mystery religion concepts at many points (Bultmann 1970; Reitzenstein 1978). In the end of a discussion of the mainstream and gnostic texts he sees the presence of goddess traditions especially in the resurrection narrative. Here he sees how other resurrection narratives like that of Osiris need a female counterpart. He concludes that at the beginning there were two redeemers: Jesus the redeemed redeemer, and the one who redeemed the redeemer, the saviour goddess Anastasis (Price 2016).

So there is a need for the goddess in the representation of the Divine, especially for the Church:

The final gift Goddess gives to Jesus is the gift of salvation. Although Christians understand Jesus as the Savior of the world, who will save Jesus from the spiritual dead end of overly masculine religion? ... She saves him from the gender-driven dualism that has plagued Christianity from its beginning. (McColman 2001:51)

He goes on to critique the results of the limited portrayal of the divine:

She especially saves him from his role as victim and martyr. The Goddess points to a new path of spirituality in which being a martyr for God is no longer necessary to win God's love ... Almost from the beginning, the followers of Jesus have interpreted his death by regarding Jesus as a willing victim thereby appeasing his angry father, the almighty God who was furious over the sins of humankind ...

The problem with this way of seeing Jesus is that it makes his greatest moment a moment of victimization and martyrdom ... Women especially are expected to be martyrs, sacrificing their personal ambitions and goals for the good of their husbands and families. Men are also expected to be martyrs, sacrificing their health and vitality to the needs of the government, the military, or corporation ... Unless a person devotes his or her life to selfdenial and sacrifice, then he or she is not truly spiritual. (McColman 2001:51-52)

McColman (2001) sees the reason for the dismissal of the goddess as a way of keeping power in the hands of a limited group of people:

But if all people sacrifice themselves, who is left to manifest true power, glory and beauty? ... If most people try to live according to principles of self-sacrifice, that leaves the majority of the wealth and power in society to the hands of a small minority of unscrupulous individuals who are not above oppressing others to consolidate their power. (p. 52) 
From this thinking he links the Wiccan tradition more tightly to the divine than patriarchal Christianity:

I believe Jesus would be sufficiently concerned about the spirituality of gender and the earth and about resisting the imbalances of mainstream religion, that he would choose the path of the Goddess - the path of Pagan, Wiccan spirituality ... I believe this because I believe Jesus was a radical in his day, and if he came today he would be just as radical ... Mahatma Gandhi once made a wry observation about Christianity, suggesting he thought it was a great idea, and he hoped someday someone will try it ... In terms of the spirit of Jesus' teachings, the Goddess community has done a much better job at embodying his message than any of the institutional churches. (McColman 2001:70-71)

I had read the stories of many goddesses, learned of the origin of the dance of the seven veils in the descent to the underworld and eventually produced the show entitled Lunacy or the Pursuit of the Goddess (Boyce-Tillman 2002) with its 12 goddesses. A visit to Egypt resurrected my goddess search. For me bringing the goddess and Jesus together became a strong vocation. It has met much opposition. I managed to get a pagan accepted in a local interfaith group, but no-one from Wicca. A tradition with a feminine Divine and priestesses is difficult for all the great faiths. The Hymn Society was also suspicious of such thinking at a time when the Divine was portrayed in the National Theatre's production of Everyman as a woman sweeping the stage. The Church and the post-secularising society were not always in tune with one another.

\section{Intergaian: Paganism and the New Age and the earth - verse 1}

In the 1980s Celtic Christianity was becoming popular in feminist Christian groups and opened up the possibility of easy relations with paganism, which chimed with my own experience. I started my hymn writing with versifying Celtic hymns which had been translated as poems:

O Christ, the holder of dark and light,

Encircle me ev'ry day, each night.

Our Lady, keeper of light and dark,

Empow'r me within your strength'ning love.

Stay close to me while I'm sleeping and

While I'm standing and while I watch,

Uphold me, embrace me gently,

O source of encompassing loveliness.

O Mary, mother of Jesus child,

Encircling arms around me fling!

O Jesus, son of Mary maid,

Fill me with the strength everlasting. (Boyce-Tillman 2006:55)

Celtic Christianity showed how religion could be inclusive. As part of the pursuit of the goddess I examined the role of the Virgin Mary as the feminine in God. The journey was rich and fruitful, opening areas of myself that I had never known. Now the ideas from these sources flow through my sermons and the hymns. Time and time again women come up to me and say that they have been thinking these things all their life and had always thought they were wrong.
In Lithuania I felt myself particularly close to my pagan roots in a country in which Christianity has been present for only 1000 years, unlike the rest of the Europe. I met a midwife in Vilnius who was reviving ancient women's ceremonies in the forests with the traditional women's songs called sutartines. Paganism enabled me to move further into the Wisdom tradition - traditionally gendered as feminine and see how gendered the Christian tradition has become in the hands of its patriarchal leaders. It enabled me to use more images drawn from the natural world, especially that of the tree, the flowers and the earth. It showed me how the earth had been marginalised by mainstream Christianity, and in my hymnody I included natural images regularly - all four elements as in this first verse. A longer song had explored this relationship more closely:

\section{CHORUS:}

Sing us our own song the song of the earth, The song of creation, the song of our birth, That exists in belonging to you and to me, To the stars and the mountains, the sky and the sea.

1. Listen! You're hearing the song of the earth, They sing it who know of their value and worth, For they know they belong with the sea and the sky, To the moonshine at midnight, the clouds floating by. CHORUS

2. It is not one song but patchworks of sound, That includes all the pitches that people have found, That includes the vibrations of earthquakes and bees, Of the laughing fire's crackling and murmuring breeze. CHORUS

3. All blend together to make the earth song,
Fragmented parts separated too long;
True notes and rhythms and colours and beat
Make sacred spaces where we all meet.
CHORUS. (Boyce-Tillman 2006:152)

The inclusion of elements from the natural world brings pagan elements into the concept of the Divine and sees the nature of the entire planet as sacred.

\section{Narrative: Christian love and St Paul - verse 2}

I had been brought up with the Christian narrative and for most of my young life had accepted it. The Christian view of love is best expressed by Paul and mostly applied to the role of women in the context of Christian marriage:

Love is patient, love is kind. It does not envy, it does not boast, it is not proud. It does not dishonor others, it is not self-seeking, it is not easily angered, it keeps no record of wrongs. Love does not delight in evil but rejoices with the truth. It always protects, always trusts, always hopes, always perseveres ... And now these three remain: faith, hope and love. But the greatest of these is love. ${ }^{6}$

The model was based on the martyrdom encouraged by a substitution theology of the cross - God giving Godself to 5.@Stainer and Bell Lto.

6.1 Corinthians 13: https://www.biblegateway.com/passage/?search=1+Corinthians+ $13 \&$ version=NIV. 
redeem the world, as we saw critiqued above in the work of McColman (2001:150-151). I had seen this in the stories of many women friends. It was an important part of the Christian narrative and served some people well and some people badly. In this verse the traditional Christian narrative of love is clearly expressed and honoured.

\section{Interpersonal: Christian love and feminism - verse 3}

But feminist theologians were challenging the traditional Christian narrative of substitution and with it, what this sort of love had meant for women over history. The normative nature of marriage was as a self-giving female with an independent male. Women were claiming independence and the marriage pattern was struggling to accommodate this. A woman's life appeared to be - in the hands of Judith Butler (1990) - a number of learned performances of which this was an important one.

I had learned this through the difficulties of an educated woman in a traditional marriage and the end of the relationship made me consider forgiveness. The older version of the Lord's Prayer gives us more clues on the mutuality of forgiveness, with the word trespass rather than 'sin'. To 'trespass' is to pass through a barrier, to encroach on the territory of someone who did not want you to come that far. If we think of the traditional scene of the barbed wire fence and 'Trespassers will be prosecuted', the boundaries of the territory are clearly defined and the would-be trespasser will probably be aware of the tear of the wire as she or he attempts to cross into a forbidden land. But if the fence is not in repair and the sign has fallen down, it is more difficult to see the boundaries.

In psychological terms, if a person does not keep her or his sacred territory well defined - the limits within which they will allow someone else to enter their own selfhood - the invading forces will have an easier task. As such, respect becomes an important aspect of relationship - when to advance, when to retreat. But, to return to the metaphor of the barbed wire and the notice, it could also be that the fences were not in good repair. In such a breakdown in a relationship, it often appears that the person who crosses the boundary is the criminal, but maybe the landowner should have kept the fences in order. It is this independent strengthening love that is celebrated in this verse. Feminism had caused marriage patterns to change and the old models no longer hold (BoyceTillman 2007:147-152, 241).

\section{Intrapersonal: The New Age seekers - verse 4}

One of the themes in the increasing religionless spirituality literature is seeking - whether into the Divine or into the self or both. To be religious implies faith in God or the divine, participation in institutionally based practices, and respect for the teachings of a tradition, but the religionless seekers have often abandoned the creeds and narratives of Christianity. According to Fuller (2001), the seeking is primarily done not in Christianity but in the New Age traditions, yoga, ecospirituality, witchcraft, near death experiences, the Tarot, astrology and neo-paganism. To be spiritual puts emphasis upon the experience of connectedness, relationship or oneness with God or Christ or a Higher Power or the sacred or nature together with an appreciation for personal growth and inner awareness in one's life journey.

Kwok Pui Lan sees a new sort of person emerging from traditional religious contexts - seekers who 'dream of new possibilities and follow their hearts' desire' (Kwok 2002:4). Robert Wuthnow (1998:vii-viii) identifies a move 'from dwelling to seeking'. His study draws on a wide variety of people and he sees a new spirituality emerging which he calls practice-based. He sees how the dwelling spirituality rooted in religious traditions is giving way to one orientated towards seeking. These people see practice rather than dwelling as a way of generating a balanced perspective on the sacredness of all the world:

Contemplative prayer ... is a prayer that sees the whole world through incense - a holy place, a place where the sacred dwells, a place to be made different by those who pray, a place where God sweetens living with the beauty of all life. Contemplative prayer ... unstops our ears to hear the poverty of widows, the loneliness of widowers, the cry of women, the vulnerability, the struggle of outcasts and so on. (Chittister 1991:35)

Wade Clark Roof (1993) entitles his book A Generation of Seekers: The Spiritual Journeys of the Baby Boomer generation. This study based on a large survey saw this generation as involved in the 1950s with institutional religion, dropping out in the 1970s. The 1980s saw a rise in born-again Christianity and the New Age, as well as complete defection from organised religion; then, in the 1990s, some religious observance returned as part of child rearing. In the end, Wade Clark Roof describes four characteristics of the baby boomers' religious or spiritual identity:

The re-emergence of spirituality - with various names such as creation spirituality, Goddess spirituality, feminist spirituality

Religious and cultural pluralism - a religion was what one chose at a time when normative faiths were challenged by the Vietnam war and the Watergate scandal

Multi-layered belief and practice - mixing and matching, citing the growth in the possibility of reincarnation within Christian frames

Transformed selves which he sees as increased sense of commitment and sense of finding oneself in a wider network of relationships. (Roof 1993:245)

Yet despite the apparently individualised nature of the spiritual search, there was also within the movement a search for community which is committed to the understanding of difference and varying identities. In this approach the health of the person and the healing of the wider community are seen as linked:

The point of spiritual practice is not to elevate an isolated set of activities over the rest of life but to electrify the spiritual impulse that animates all of life. (Wuthnow 1998:198) 
The seeking is often coupled by a loosening of the hold of particular dogma - or what I have called Narrative. Brian McLaren (2010), in a book interestingly called Naked Spirituality, describes a move from trusting sciences for all the answers, a distrust of organised religion, a sense of universal sacredness and the popularity of spiritual practices such as meditating. Miner and Dowson (2012) draw a number of these themes together in their definition of spirituality:

In the context of spiritual experience, spirituality is the search, beyond psychology and physicality, for meaning, transformation, and connectedness ..., success in which leads to new patterns of understanding, becoming and relating. (p. 18)

So, many writers see searching as a central feature of contemporary spirituality. This contrasts with the dwelling that characterises religious affiliation and subscription to a particular narrative. It is this that I attempted to capture in this wandering verse.

\section{Extrapersonal - The merging of narratives - verse 5}

It is the last verse that has proved problematic. It is the first to use words from the Christian Narrative, but here combined with ones from Greek and Roman paganism. In the final verse the descriptor Holy Ghost is used deliberately to counteract the 'shades of ancient bitterness'. I had been brought up with the term Holy Ghost as a cradle Anglican, but Holy Spirit has replaced it in much contemporary worship. Ghost is considered archaic, but the entry into the New Age tradition had meant an encounter with the idea of reincarnation in which I had regained an idea of a ghost or spook.

The use of religious language in the verse has resulted in its omission from some services, like the one for healing violence against children. It has also undergone various changes. Here are some of the versions that have appeared, taken from the internet:

VERSION ONE: We sing the Holy Spirit, full of love,

Who seeks out scars of ancient bitterness,

Brings to our wounds the healing grace of Christ;

Come, radiant love, live in our hearts today.

VERSION TWO: We sing a burning, fiery, Spirit free

That seeks out shades of ancient bitterness,

Trans fig'ring these, as Christ in ev'ry heart.

Come, joyful love, live in our hearts today.

VERSION THREE: We seek a burning, fiery, Holy One,

That seeks out shades of ancient bitterness.

Transfigure these as Christ in every heart,

Come, joyful love, live in our hearts today.

VERSION FOUR: We sing a burning, fiery, Holy Ghost

That seeks out shades of ancient bitterness,

Transfig'ring these, as God in ev'ry heart.

Come joyful love, live in our hearts today.

VERSION FIVE: We sing a burning, fiery, Holy Power

That seeks out shades of ancient bitterness,

Transfig'ring these, as God in ev'ry heart.

Come, joyful love, live in our hearts today. ${ }^{7}$

7.These versions have been taken from a variety of websites containing various orders of service.
These modifications reveal a great deal about modern postsecularism and the acceptable words to describe the Divine. Spirit is acceptable and found in both New Age and Christian traditions, but it needs a rework of this verse because of the metre. The use of the term shades is regarded as too pagan in some circles and is replaced with scars. Modern psychoanalysis has made the concept of possession by spooks as superstitious, pathological or out-of-date. Christ is also problematic, although in New Age circles it has often been uncoupled from Jesus. The word One with a capital letter is useful, as metrically its one syllable replaces Ghost easily. Power is similar and also links with the use of the term Higher Power in the 12 Step programme.

Similarly, the verb transfiguring in one version has been turned into a request or prayer, whereas the original saw this as an ongoing process continually happening. In these changes we see places where dialogues between traditions or even with the past are not considered appropriate. The separate Narratives are to be kept separate, whereas in other contexts such construction of new Narratives from a variety of traditions is considered not only acceptable but desirable in the pursuit of a perennial philosophy (Huxley 1945) - a way of healing divisions between religious traditions. Here we see some of the acceptable words for the Divine in a post-secular society and how history plays out in the choices made.

\section{Conclusion}

This article has tracked a personal journey through an autoethnographic crystallisation methodology. It has done this through the story of a hymn originally written for a Christian wedding. It has seen how it was constructed using strands now apparent in the descriptor spiritual in a post-secular society. It has seen how these trends are intimately related to the dominant religion of pre-secularising society and are often attempts to rebalance certain characteristics within it. It sees the possibility of a radical new spirituality that brings together body and soul, male and female authority, Jesus and the Goddess, and Christian spirituality and pagan practice through exploring a variety of descriptors for the Divine. It sees this, as in the first verse, as profoundly liberating. The hymn has attempted to form a bridge between various traditions and has shown how this has been received in a post-secular society.

\section{Acknowledgements Competing interests}

The author declares that she has no financial or personal relationships that may have inappropriately influenced her in writing this article.

\section{References}

Assagioli, R., 1994, The act of will, Aquarian/Thorsons, London, originally published 1974.

Boyce-Tillman, J., 2000, Constructing musical healing: The wounds that sing, Jessica Kingsley, London. 
Boyce-Tillman, J., 2001/2012, The healing of the earth, reworked 2012 for Winchester Cathedral, The Hildegard Press, London.

Boyce-Tillman, J., 2002, Lunacy or the Pursuit of the Goddess, Unpublished onewoman performance, Plymouth, UK.

Boyce-Tillman, J., 2006, A rainbow to heaven, Stainer and Bell, London.

Boyce-Tillman, J., 2007, Unconventional wisdom, Equinox, London.

Boyce-Tillman, J., 2009, 'The transformative qualities of a liminal space created by musicking', Philosophy of Music Education Review 17(2), 184-202. https://doi. org/10.2979/PME.2009.17.2.184

Boyce-Tillman, J., 2014, In tune with heaven or not: Women in Christian liturgical music, Peter Lang, Oxford.

Boyce-Tillman, J., 2016, Experiencing music-restoring the spiritual: Music as wellbeing Peter Lang, Oxford.

Boyce-Tillman, J. \& Wootton, J. (eds.), 1993, Reflecting praise, Stainer and Bell and Women in Theology, London.

Bringle, M.L., 2002, Joy and wonder, love and longing: 75 hymn texts, GIA Publications, Chicago, IL.

Buber, M., 1970, I and thou, transl. W. Kaufmann, Charles Scribner's Sons, New York.

Bultmann, R., 1970, Theology of the New Testament: Complete in one volume, Prentice Hall, Upper Saddle River, NJ.

Butler, J., 1990, Gender trouble: Feminism and the subversion of identity, Routledge, London.

Carrette, J., 2000, Foucault and religion: Spiritual corporality and political spirituality, Routledge, London.

Chittister, J., 1991, Wisdom distilled from the daily: Living the rule of St. Benedict today, HarperCollins, New York.

Clarke, I., 2008, Madness, mystery and the survival of God, O Books, Ropley.

Daw, C.P., Jr., 1996, New Psalms and Hymns and spiritual songs, Hope Publishing, Carol Stream, IL.

Daw, C.P., Jr., 2003, Unpublished Interview at Boston University, MA, 27th April 2003.

Dawkins, R., 2007, The god delusion, Black Swan, London.

Ellingson, L., 2009, Engaging crystallization in qualitative research: An introduction, Sage, London.

Fiorenza, E.S., 2000, Jesus and the politics of interpretation, Continuum, New York.

Fuller, R., 2001, Spiritual but not religious: Understanding unchurched America, Oxford University Press, Oxford.

Grey, M., 1993, The wisdom of fools: Seeking revelation for today, SPCK, London.

Grey, M., 2007, 'Ecomysticism: A contemporary path of Christian healing', in J. Baxter (ed.), Wounds that heal: Theology, imagination and health, pp. 36-56, SPCK, London.

Haraway, D., 1988, 'Situated knowledges: The science question in feminism and the privilege of partial perspective', Feminist Studies 14(3), 575-599. https://doi. org $/ 10.2307 / 3178066$

Huxley, A., 1945, The perennial philosophy, Harper and Brothers, New York.

Isherwood, L. \& Stuart, E., 1998, Introducing body theology, Sheffield Academic Press, Sheffield

James, W., 1902/ 1997, The varieties of religious experience, Simon and Schuster, New York, originally published 1903.

Jorgensen, E.J., 2008, The art of teaching music, Indiana University Press, Bloomington, IN.

Kendrick, G., 2003, 'Worship in spirit and truth', in S. Darlington \& A. Kreider (eds.), Composing music for worship, pp. 86-10, Canterbury Press, Norwich.

Koestler, A., 1964, The act of creation, Hutchinson, London.

Kwok, P.L., 2002, 'Spiritual and also religious?', The Brown Papers IV(3), Brown Paper Press, Long Beach, California.
Lancaster, B.L., 2004, Approaches to consciousness: The marriage of science and mysticism, Palgrave Macmillan, London.

Laurence, F., 2008, 'Music and empathy', in O. Urbain (ed.), Music and conflict transformation: Harmonies and dissonances in geopolitics, pp. 13-25, I.B.Tauris, London.

McColman, C., 2001, Embracing Jesus and the Goddess: A radical call for spiritual sanity, Fair Winds Press, Gloucester, MA.

McEwan, D., Pinsent, P., Pratt, I. \& Seddon, V., 2001, Making liturgy: Creating rituals for life, Canterbury Press, Norwich.

McLaren, B.D., 2010, Naked spirituality, Hodder and Stoughton, London.

Mantin, R., 2002, 'Thealogies in process: The role of goddess-talk in feminist spirituality', Unpublished PhD thesis, Southampton University.

Michaels, P., 2003, Interview at St. James' Episcopal Church in Porter Square in Cambridge, MA, January 31st 2003.

Miner, M. \& Dowson, M., 2012, 'Spirituality as a key resource for human glourishing', in M. Miner, M. Dowson \& S. Devenish (eds.), Beyond well-being - Spirituality and human flourishing, pp. 5-31, Information Age Publishing, Charlotte, NC.

Murray, S.E., 1996, Every day in your spirit, Hope Publications, Chicago, IL.

Myers, I.B., 1993, Gifts differing: Understanding personality type, Consulting Psychologists Press, Palo Alto, CA, originally published 1980.

Myers, I.B. \& McCaulley, M.H., 1985, Manual: A guide to the development and use of the Myers-Briggs type indicator, 2nd edn., Consulting Psychologists Press, Palo Alto, CA.

Neu, D.L., 2003, Women's rites: Feminist liturgies for life's journey, The Pilgrim Press, Cleveland, $\mathrm{OH}$.

Pratt, D., 2012, 'The persistence and problem of religion: Exclusivist boundaries and extremist transgressions', in Keynote address at the Conference of the British Association for the Study of Religion, University of Winchester, September 06.

Price, R., 2016, The Christ Myth and the Christian Goddess, n.p., viewed 17 January 2016, from http://www.robertmprice.mindvendor.com/art_christgoddess.htm

Primavesi, A., 2008, Gaia and climate change: A theology of gift events, Boomerang Books, Sydney.

Raphael, M., 1999, Introducing thealogy: Discourse on the goddess, Sheffield Academic Press, Sheffield.

Reitzenstein, R., 1978, Hellenistic mystery religions - Their basic ideas and significance, Pickwick Press, Eugene, OR.

Richardson, L., 2000, 'Writing: A method of enquiry', in N.K. Denzin \& Y.S. Lincoln (eds.), Handbook of qualitative research, pp. 923-943, Sage, Thousand Oaks, CA.

Roof, W.C., 1993, A generation of seekers: The spiritual journeys of the baby boomer generation, HarperSanFrancisco, New York.

Silvestro, M., 1993, On the other side: Songs that celebrate many ways of knowing, Moonsong Productions, Cassette Gloucester, MA.

Stuart, E., 1996, Just good friends: Towards a lesbian and gay theology of relationships, Mowbrays, London.

Tisdell, E., 2007, 'In the new millennium: The role of spirituality and the cultural imagination in dealing with diversity and equity in the higher education classroom', Teachers College Record 109, 531-560.

Turner, V., 1982, From ritual to theatre: The human seriousness of play, PAJ Publications, New York.

Unitarian/Universalist Hymnbook Resources Commission, 1993, Singing the living tradition, Beacon Press, Boston, MA.

Wren, B., 1989, What language can I borrow? SCM Press, London.

Wootton, J.H., 2000, Introducing a practical feminist theology of worship, Sheffield Academic, Sheffield.

Wootton, J., Rev Dr., 2003, Interview at Union Chapel. Islington, London, July 2003.

Wuthnow, R., 1998, After heaven: Spirituality in America since the 1950s, University of California Press, Berkeley, CA. 